\section{anthropology \& materialism}

\section{Anthropology \& Materialism}

A Journal of Social Research

1 | 2013

Across the Fields

\title{
The Messianic Without Messianism
}

Walter Benjamin's Materialist Theology

Le messianique sans messianisme. La théologie matérialiste de Walter Benjamin

Lo mesiánico sin mesianismo. La teología materialista de Walter Benjamin

\section{Sami Khatib}

\section{OpenEdition}

\section{Journals}

\section{Electronic version}

URL: http://journals.openedition.org/am/159

DOI: 10.4000/am.159

ISSN: 2364-0480

Publisher:

CETCOPRA, CRASSH - Center for Research in the Arts Social Sciences and Humanities, Fakultät

Gestaltung - Universität der Künste Berlin

\section{Electronic reference}

Sami Khatib, "The Messianic Without Messianism », Anthropology \& Materialism [Online], 1 | 2013 Online since 15 October 2013, connection on 19 April 2019. URL : http://journals.openedition.org/ am/159 ; DOI : 10.4000/am.159

This text was automatically generated on 19 April 2019

Tous droits réservés 


\title{
The Messianic Without Messianism
}

\author{
Walter Benjamin's Materialist Theology \\ Le messianique sans messianisme. La théologie matérialiste de Walter Benjamin \\ Lo mesiánico sin mesianismo. La teología materialista de Walter Benjamin
}

\section{Sami Khatib}

\section{AUTHOR'S NOTE}

This article is broadly based on a reedited paper presented at the "Jews and Revolutions" conference, Leo Baeck Institute, Jerusalem, March 2, 2011. A Hebrew translation will be published in a special issue of the journal Chidushim - Studies in the History of German and Central European Jewry (Jerusalem: Leo Baeck Institute).

\section{Introduction}

\author{
"History is not the past. History is the past in so far \\ as it is historicised in the present - historicised in \\ the present because it was lived in the past." \\ Jacques Lacan
}

1 In Specters of Marx, Jacques Derrida extracted the notion of the messianic from its religious shell and Abrahamic legacy. Critically echoing the triumphant teleologies of capitalist world history as they were announced after the collapse of 'actually existing socialism,' Derrida draws a line from the unexorcisable specters of Marx that haunt capitalism's never accomplished ontology to an atheist legacy of the messianic promise. Stressing the "quasi-atheistic dryness of the messianic," he calls for a "messianism without religion, even a messianic without messianism" (Derrida 1994: 211, 74).

2 Taking its cue from this atheist reading, this article turns Derrida's hypothesis upside down. Although the messianic can never be fully disentangled from its Jewish and Judeo- 
Christian legacy, I conceive of it as a profane figure. ${ }^{1}$ In contrast to Derrida, Benjamin does not claim "an atheological heritage of the messianic" (Derrida 1994: 211). ${ }^{2}$ However, the underlying hypothesis of this article is that any attempt to fully translate Benjamin's messianic thought into the language of theology, misses the radical Entstellung, deformation and displacement, that Benjamin's (de)figuration of the messianic figured. ${ }^{3}$ In this respect, my reference to Derrida's take on the messianic as messianicité sans messianisme is only of heuristic nature. Derrida provides us with a heuristic model to relocate the site of the messianic beyond the thought pattern of theological original and secularized double.

Messianicity (which I regard as a universal structure of experience, and which cannot be reduced to religious messianism of any stripe) is anything but Utopian: it refers, in every here-now, to the coming of an eminently real, concrete event, that is, to the most irreducibly heterogeneous otherness. Nothing is more 'realistic' or 'immediate' than this messianic apprehension, straining forward toward the event of him who/that which is coming. (Derrida 1999: 248)

In difference to Derrida, however, for Benjamin the messianic is not about an "irreducibly heterogeneous otherness" but about an inaccessible relation, an intensive tension that relates the historical happening to redemption - in an a-teleological way. If Derrida reminds us of the crucial difference between telos and eschaton ${ }^{4}$, we have to add with Benjamin that the structure of redemption leaves an irreducible theological remainder. Although the historical happening has no trans-historical goal or telos - be it classless society or the messianic Kingdom -, history evinces a messianic directedness to redemption. As I will argue, this reference to redemption is not about theology proper but about 'something' that exceeds the domains of scientific knowledge, religious beliefs, and political ideologies. The messianic does not allude to a radical alterity or a mystical secret but bears witness to a lack, an incompleteness that prevents the order of the profane from ultimately being closed as a self-totalizing sphere.

\section{Messianic Time}

In 1917, Franz Kafka noted: "The messiah will only come when he is no longer necessary; he will come only on the day after his arrival; he will come, not on the last day, but the very last." ${ }^{5}$ If the Messiah is not coming in time - neither in the kairological nor in the chronological sense - there is no point in endlessly waiting for his coming. Without any further delay or deferral, the Messiah will come after his arrival - that is, after we will have done the profane work of redemption, which the Messiah will not do for us. Hence, the profane task of politics consists in keeping the Messiah's place empty before his arrival and refraining from occupying it in a theocratic manner.

5 Taking my cue from Kafka's cryptic fragment, I return to Benjamin's dialectical (if not paradoxical) understanding of the messianic. Benjamin shares a basic insight with Kafka: If the Messiah will only come after his arrival, there is no such thing as messianic politics. Moreover, the messianic tendency of history is not to be found in a messianic direction. The hope for redemption has no messianic horizon of expectation; rather, it orients itself toward the opposite direction - the direction of the profane. In this sense, we might read the paradoxical formula at the end of Benjamin's essay on Goethe's Elective Affinities: "Only for the sake of the hopeless ones have we been given hope" (SW 1: 356). ${ }^{6}$ Here, hope is not an individual attitude directed to the future but something we have been given by 
those who lived before us. The paradoxical hope of the hopeless ones is derived and discontinuously transferred from the past. And it is only this openness to the past that can give rise to a future, which is not the mere continuation of the past.

6 The past is the non-accomplishable subject matter of historiography and in this sense Benjamin's messianic thinking is always bound to a philosophy of history, or, more precisely, to a messianic re-conceptualization of the concept of historical time upon which every concept of history hinges. For Benjamin, a truly historical concept of history cannot be based on a linear, successive, and mechanic time but only on a non-linear, abbreviated, and condensed time. As Benjamin states in his famous $14^{\text {th }}$ thesis On the Concept of History (1940), "[h]istory is the subject of a construction whose site is not homogenous, empty time, but time filled full by now-time [Jetztzeit]" (SW 4: 395). The theological name of this filled full, fulfilled time is messianic time. Benjamin, however, does not deploy a theological concept within the profane field of history; rather he displaces the messianic actuality to the field of revolutionary politics without identifying it with the latter. "What characterizes revolutionary classes at their moment of action is the awareness that they are about to make the continuum of history explode" (ibid.). It is only this explosive tension that maintains a structural correspondence to the disruptive break of time commonly associated with the apocalyptic trend of messianic thinking. As we shall later see, Benjamin's messianic thought is dialectical - it is also related to the mythical transformation, a "slight adjustment" in the world. ${ }^{7}$

7 For the moment, I will tarry with Benjamin's revolutionary and profoundly modernist understanding of messianic time. Benjamin's historico-philosophical references to the messianic can be traced back to his early writings linking his thought to the tradition of early romantic messianism which he explicitly referred to in his dissertation on the romanticist concept of Kunstkritik from 1919. Quoting from a famous fragment of Schlegel's Athenäum Benjamin writes:

The revolutionary desire to realize the kingdom of God on earth is the elastic point of progressive civilization [Bildung] and the beginning of modern history. Whatever has no relation to the kingdom of God is of strictly secondary importance in it. ${ }^{8}$

As counter-intuitive as it might sound, in Benjamin's reading of Schlegel, the messianic is not a secularized remainder from pre-secular religious tradition but a profoundly modern or even modernist experience underlying the foundation of the modern concept of history. For the latter is not derived from a quasi-scientific, Newtonian concept of time but originates from the experience of a profane event and its founding gesture: the French revolution. Hence, instead of opposing secular history proper and a theological Judeo-Christian model of Heilsgeschichte [salvation history], the revolutionary desire or drive to revolutionary anticipates the Messiah before his arrival, introducing a messianic tension into the otherwise "homogeneous, empty time" and the flat historical experience of the age of enlightenment. In his Star of Redemption from 1921, Franz Rosenzweig highlighted the specifically historical temporality introduced by German early romanticism:

Without this anticipation and the inner pressure to realize it, without 'the desire to make the Messiah arrive before his time' and the attempt 'to do violence to the heavenly Kingdom', the future is not a future, but only a past drawn out to an infinite length, a past projected forward. For, without this anticipation, the moment is not eternal but something that interminably crawls along the long strategic roadway of time. (Rosenzweig 2005: 244) 
In other words, for every future-oriented quietism - be it secular as social democratic evolutionism, or theological as an eternal deferment of the coming of the Messiah - there is no future proper. Historical time in its modern sense requires a certain tension without being necessarily oriented towards a final eschaton as its telos. From a political standpoint, Schlegel's romantic messianism touches upon the interdependency of the object of historiography and the subject of history, the latter of which Marx famously conceived of as the proletariat.

Taking his cue from early romanticism, the early Benjamin rejected any evolutionist or progressivist concept of history. Already in a speech held at a student assembly in 1914, Benjamin addressed his audience with the following remark: "The elements of the final state do not appear as a formless tendency of progress but are deeply embedded in every present as the most endangered, most infamous, and most ridiculed creations and thoughts." Consequently, his messianic thought was oriented towards the marginal elements of the actual historical situation in which he lived. Instead of watching for some future signs he drew his attention to the mostly overlooked, obscured or forgotten signs of the actual presence. Although Benjamin's thinking underwent radical changes and ruptures - most notably his political and theoretical orientation towards Marxism after 1924 - he followed the trajectory of his early impetus against the idea of progress.

11 In the 1930 and especially in his last theses On the Concept of History, Benjamin proposed his own reading of historical materialism, resulting in a radical revision of vulgar Marxism the significance of which is, according to Michael Löwy, only comparable to Marx's theses on Feuerbach. ${ }^{10}$ For Benjamin history is not based on the linear flow of "homogeneous, empty time" (SW 4: 395) but on a disruptive constellation of the present and the past. The later Benjamin, however, adds a decisive feature to this non-diachronic concept of historical time. Within the historical discontinuum of the "tradition of the oppressed" (SW 4: 392) lost causes and struggles of the past are not diachronically strung together but synchronistically connected and can be politically "recapitulated"11 in the present. This recapitulation or repetition, Wieder-holung [literally: bringing back], cannot be intentionally enacted since the "weak messianic power" (SW 4:390) of past generations cannot intentionally be conjured. It is only by way of a messianic openness beyond the dichotomies of activity and passivity, intentional acting and non-intentional meditation that the radically partisan and politically involved collective - the "struggling, oppressed class" (GS I: 1243) - can account for history's weak messianic power by taking up the latter's addressing. Before I turn to the dialectics of this messianic addressing, let me dwell on the explicitly political aspect of Benjamin's revision of historical materialism.

In the draft version [Handexemplar] of theses On the Concept of History, Benjamin clarified his stance towards Marx, messianic thought, social democratic evolutionism, vulgarMarxist economic determinism, and neo-Kantian idealism.

In the idea of classless society, Marx secularized the idea of messianic time. And that was a good thing. It was only when the Social Democrats elevated this idea to an 'ideal' that the trouble began. [...] For the revolutionary thinker, the peculiar revolutionary chance offered by every historical moment gets its warrant from the political situation. But it is equally grounded, for this thinker, in the right of entry which the historical moment enjoys vis-à-vis a quite distinct chamber of the past, one which up to that point has been closed and locked. The entrance into this chamber coincides in a strict sense with political action, and it is by means of such entry that political action, however, destructive, reveals itself as messianic. (Thesis 17a, SW 4: 401f.) 
13 Paradoxically, for Benjamin profane history can only be truly historical insofar as it stands in an antithetical and undecidable relation to messianic time, which for Marx as well as for the late Benjamin is the idea of classless society. Benjamin's affirmation of Marx's secularization of messianic time is thus not strictly atheist. Rather, it maintains a contradictory relation - a relation of a non-relation - to the messianic. This relation is not directed toward a theological telos but accounts for a certain temporal constellation, short-circuiting past and present as now-time [Jetztzeit] and thereby arresting the linear, irreversible flow of "homogeneous, empty time." Such a "conception of the present as now-time shot through with [punctuated by] splinters of messianic time" (SW 4: 397) is not to be mistaken for esoteric mysticism; Benjamin's disruptive and non-linear concept of historical time aims at the revolutionary encounter of past and present modeled after the name of the communist Spartakusbund of Rosa Luxemburg and Karl Liebknecht. It is in this sense that Benjamin affirms political action, however, destructive, it reveals itself as messianic. Revolutionary redemption, hence, cannot be separated from its destructive element relating Benjamin's late Marxism to his early anarchism and its theoretical counterpart, nihilism.

\section{Messianic Nihilism}

Benjamin never fully abandoned his early political anarchism and messianic nihilism even after his Marxist re-orientation in 1924. Instead of revoking his a-teleological anarchism Benjamin claims in a letter from 1926 that there are no political goals at all not even communist goals. ${ }^{12}$ This peculiar form of nihilism, however, is not identical with a Nietzschean anti-religious nihilism since it distills from both atheist and inner-religious traditions of nihilism (cf. Wohlfarth 2002: 153). From a theological viewpoint, Benjamin's nihilism does not tarry with the mystical nihil, the Nichts but seeks to overcome it in terms of redemption. As Irving Wohlfarth convincingly argued, the basic underlying structure of his messianic thought remains triadic following a theological schema: primordial unity (paradise) - historical separation (revelation) - eternal restitution (redemption) (cf. Wohlfarth 1979). In contrast to a common understanding of this triadic schema, for Benjamin the last stage - be it modeled after the early Christian idea of apokatastasis or the mystic-Jewish motif of tikkun - is conceived of in an a-teleological manner rendering it impossible to relate the historical happening itself to its last stage, its messianic fulfillment.

In the above-mentioned Theological-Political Fragment, which was probably written in the early $1920 \mathrm{~s}^{13}$, Benjamin clearly denies any historical striving towards a messianic goal, for "[o]nly the Messiah himself completes all history, in the sense that he alone redeems, completes, creates its relation to the Messianic." "Therefore", as the fragment proceeds, "the Kingdom of God is not the telos of the historical dynamic: it cannot be established as a goal. From the standpoint of history, it is not the goal but the terminus [Ende]" (SW 3: 305). ${ }^{14}$ Since we are standing in the unclosed net of history we cannot relate ourselves to the messianic: the ground of this messianic relation is subtracted from the historical happening to the Messiah himself. Benjamin holds on to this strictly anti-theocratic distinction between the order of the profane and the order of the messianic Kingdom laying bare his radically profane concept of politics. Following this impetus, Benjamin thinks of an a-teleological relation of history and its messianic terminus (Abbruch). The messianic end of history is not derived from history's own fulfilling movement or its 
coming-to-itself like at the end of Hegel's Phenomenology of Spirit. In contrast to a Hegelian-Christological perspective of the Last Judgment when all historical events will have been decided, Benjamin affirms an irreducibly historical standpoint, from which neither an idealist Utopia of the messianic Kingdom nor the final accomplishment of history can be envisioned or anticipated. In line with this a-teleological stance, Benjamin implicitly suggests an self-voiding of the personal Messiah. Throughout his entire body of work, there are only very few occasions where Benjamin directly refers to the Messiah as a person; these occasions, however, are too important to be ignored or simply metaphorized. Dwelling on these rare references, Jacob Taubes famously denounced an impersonal understanding of the Messiah in Benjamin: "There is a Messiah. No schmonzes like 'the messianic', 'the political', no neutralization but the Messiah." ${ }^{15}$ Nevertheless, I argue that we can detect the figure of the 'messianic' in Benjamin, which is neither a schmonzes nor a neutralization of the Messiah.

Regarding the Theological-Political Fragment, we might speak of a radical absence, an emptiness, or a self-voiding of the personal Messiah. Unlike in negative theology, however, for Benjamin the absent Messiah is not defined after the model of the deus absconditus or "hidden god" since his subtraction from history leaves an empty imprint, a signature, a weak messianic power within the historical happening. Moreover, it is precisely through his absence from the historical happening that the Messiah creates a messianic tension within history, indirectly referring the latter to redemption, to a profane restitutio in integrum. This paradoxical tension is called the messianic. The 'relation' of the historical to the messianic thus does not indicate a direct relation but an antithetical relation of a non-relation, that is, an 'a-relation'. From the standpoint of history, this 'a-relation' must not be defined in a religious way - it remains a relation of a non-relation, a connection through division. That is why Benjamin repudiates the political meaning of theocracy limiting the latter to the domain of religion (cf. SW 3: 305). As Werner Hamacher argued the Theological-Political Fragment - a title given posthumously by Adorno - should be better called the "Political-Atheological Fragment." 16 There is no theological doctrine, no positive knowledge of the messianic. We cannot state it theoretically, transcendentally or prove it empirically. Hence, the paradoxical messianic tension within history remains inaccessible, a-teleological and non-intentional without being fully delegated to the misty realm of mysticism and the endless work of interpretation and deciphering.

17 Since the messianic cannot be graphically depicted, Benjamin enlists the help of a figurative image, which - as always in his writings - does not simply transfer a fixed meaning by means of a secondary metaphor but is itself a Thought-Image or Denkbild presenting rather than merely representing the signified relation.

The order of the profane should he erected on the idea of happiness. The relation of this order to the Messianic is one of the essential teachings of the philosophy of history. It is the precondition of a mystical conception of history, encompassing a problem that can be represented figuratively. If one arrow points to the goal toward which the profane dynamic acts, and another marks the direction of Messianic intensity, then certainly the quest to free humanity for happiness runs counter to the Messianic direction. But just as a force, by virtue of the path it is moving along, can augment another force on the opposite path, so the profane order of the profane promotes the coming of the Messianic Kingdom. The profane, therefore, though not itself a category of this Kingdom, is a decisive category of its quietest approach. For in happiness all that is earthly seeks its downfall, and only in happiness is its downfall destined to find it. Whereas admittedly, the immediate 
Messianic intensity of the heart, of the inner man in isolation, passes through misfortune, as suffering. To the spiritual restitutio in integrum, which introduces immortality, corresponds a worldly restitution that leads to the eternity of downfall, and the rhythm of this eternally transient worldly existence, transient in its totality, in its spatial but also in its temporal totality, the rhythm of Messianic nature, is happiness. For nature is Messianic by reason of its eternal and total passing away. To strive for such a passing away - even the passing away of those stages of man that are nature - is the task of world politics, whose method must be called nihilism. (SW 3: 305f.) $)^{17}$

18 Although this notoriously enigmatic and dense passage demands a close reading, let me tentatively draw some first conclusions: Instead of positing the messianic as an ethical ideal or a religious goal, humanity has to move in a strictly profane direction. The messianic direction cannot be addressed or pointed at directly but can only be indirectly promoted in the order of the profane. From the viewpoint of a Benjaminian messianic nihilism, the profane striving has no end-goal - it leads into an "eternal and total passing away." This movement of transiency never reaches the final stage when all tension is resolved, when all life has returned into a nihil, nothingness, or, to put it into Freudian terms, when all lively tension has entered the tentionless state of a Nirvana-Principle. Rather, we have to understand this striving strictly a-teleologically. Benjamin's name of the messianic rhythm of the declining movement of the profane order is happiness. And happiness is indeed, as Jonathan Lear comments on Aristotle and Freud, "not the ultimate goal of our teleologically organized strivings, but the ultimate ateleological moment: a chance event going well for us - quite literally, a lucky break" (Lear 2000: 129). ${ }^{18}$ It is in this truly profane and a-teleological sense that we should understand Benjamin's idea of happiness: as a disruptive break (re)opening "possibilities for new possibilities" (ibid.) that were foreclosed in the past. The profane restitutio in integrum is nothing else than the restitution of happiness as the movement of restoring the possibility for new possibilities. The striving for happiness thus is not aimed at a goal - that is the ultimate entrance into a world of bliss - but concerns the disruptive opening up of a profane life locked up in a world of fate and coercion. ${ }^{19}$

19 The profane striving for happiness, however, is not messianic itself but the profane driving force of the profane and, therefore, has to be strictly differentiated from the order of the divine. But how are we to conceive of the two opposing forces [Kräfte] promoting each other if the driving force of the profane and coming of the messianic Kingdom belong to heterogeneous orders? Let me concentrate on two aspects to unravel this paradoxical image:

20 (1) The mutual promotion of two opposite forces does not seek a final release or Aufhebung, sublation; there is no higher degree of dialectical identity, no Hegelian synthesis as a sublating unity of the two opposing extremes; rather the opposing poles of the profane dynamis and the messianic intensity remain separated, for the profane is not itself a category of the messianic Kingdom "but only a decisive category of its quietest approach." This approaching to, anticipating of, or pointing at the messianic Kingdom remains intensive; it cannot be converted into an extensive reality. In other words, the identity of these two powers - the messianic and the profane - can never be posed as a telos of their opposed strivings. There remains a gap, a division that keeps the tension between these antithetical poles. With the idea of happiness, a non-linear, a-teleological and messianic rhythm is implied which leads into the "eternity of downfall" - a rather opaque formulation that could be linked to the Freudian notion of death-drive 
understood as a derailing striving having no final goal and, therefore, reaching beyond the pleasure principle. ${ }^{20}$ However, the initial question remains: how can two opposing forces promote each other without turning into a third stage in which their theological and profane poles are sublated to a higher principle? Or, rather, does the question of the very distinction between the two poles already imply its answer? Although Benjamin separates the messianic from the profane direction, there seems to be a standpoint where the difference of these two poles somehow disappears without mingling them. There is much evidence that Benjamin's peculiar form of a non-Hegelian dialectic between two opposing poles was inspired by Salomo Friedlaender and his philosophical main work Schöpferische Indifferenz, [Creative Indifference] from 1918. According to Benjamin's reading of Friedlaender, "creative indifference" does not designate the geometrical half-way, the middle between two extreme poles; it rather marks the banned site of an event, the discharge of a tension. ${ }^{21}$ In other words, there can be a site, a zone of creative indifference of opposing poles without sublating them to a higher unity. The paradox of an unmediated mediation does not only affect the difference of the profane and the theological or of the historical and the messianic but also Benjamin's own political standpoint. In 1926, after his Marxist re-orientation, he writes in a letter to Scholem: "I speak here of an identity which emerges only from the paradoxical reversal [Umschlagen] (in whatever direction) of one into the other, the indispensable precondition being that action is contemplated unconditionally and radically enough. [...]. Always radically, never consistently [Immer radikal, niemals konsequent]." ${ }^{22}$ According to Wohlfarth (1986), we might take this as a motto of Benjamin's entire - not only political - thought.

21 (2) Although Benjamin invokes an image of two symmetric counter-forces striving in opposite directions, these two Kräfte, forces or powers, seem to be heterogeneous. Whereas one power is a 'powerful power' belonging to the spatially and temporally transient order of the profane extensively working in a profane direction and seeking its "eternal and total passing away", the other "power" is an intensity working from within history: an intensive power without extensive power. If the dynamis of the profane is the striving for happiness, the messianic power-without-power transforms, displaces and ultimately decouples every individual striving: like a messianic vector-change it derails the teleological vector running from the striving to its goal, the state of happiness. The temporality of this derailment or decoupling is not disruptive but rhythmic: in the rhythm of happiness the world passes away in eternal transience.

If we consider Benjamin's later essay On the Image of Proust (1929/34), we can discern the dialectics of this rhythm: "There is a dual will to happiness, a dialectics of happiness: a hymnic form as well as an elegiac form. The one is the unheard-of, the unprecedented, the height of bliss; the other, the eternal repetition, the eternal restoration of the original, the first happiness" (SW 2.1: 239). The dialectical intertwinement of eternal repetition and the unprecedented forms a temporal curve, which cannot be represented within the register of linear succession. As we will see, the historical-philosophical relevance of the idea of happiness resides in its peculiar temporality, which allows for both the (revolutionary) break of the radical new and the (transformative) restoration of something that has never happened before. 


\section{A weak messianic power}

23

Almost 20 years after the Theological-Political Fragment, Benjamin returned to his idea of happiness, placing it at the heart of the $2^{\text {nd }}$ thesis On the Concept of History. In contrast to the earlier fragment, however, an affective and historical-temporal dimension comes into play: in happiness we are exposed to an unfulfilled history of past generations striving for their retroactive redemption.

[...] the image of happiness we cherish is thoroughly colored by the time to which the course of our own existence has assigned us. There is happiness - such as could arouse envy in us - only in the air we have breathed, among people we could have talked to, women who could have given themselves to us. In other words, the idea of happiness is indissolubly bound up with the idea of redemption. The same applies to the idea of the past, which is the concern of history. The past carries with it a secret index by which it is referred to redemption. [...] If so, then there is a secret agreement between past generations and the present one. Then our coming was expected on earth. Then like every generation that preceded us, we have been endowed with a weak messianic power, a power on which the past has a claim. Such a claim cannot be settled cheaply. The historical materialist is aware of this. (SW 4: $389)^{23}$

In the idea of happiness, past and present are connected in a non-causal and non-linear way. Benjamin blends the levels of individual experience, that is (missed) chances for happiness, with a transindividual address that earlier generations transmit to present generations. Therefore, also in a historical-philosophical sense, past and present are irreducibly connected - without being causally determined in an external way. This connection consists in a directed and non-reciprocal relation that past generations share with the present ones. It is this relation, an affective relation through singular and personal moments of happiness, that is universally directed to redemption. It is not that the present or the future can directly redeem preceding times. Rather, redemption here only concerns this relation and its a-teleological directedness. The German word Er-lösung [redemption] also connotes Lösung [release], which is part of the German word for the strictly profane meaning of redemption: Ein-lösung. If there is a non-reciprocal relation of a political-ethical indebtedness of past and present generations - an irrefusable claim -, only the present generation has the key to redeem this relation. However, the present can also ignore this claim and forever miss a chance to redeem its relation to the past. Therefore, from the perspective of the past, this relatedness to redemption is weak; there is no guarantee that the present will recognize its intendedness by the past. If redemption, happiness, and time are irreducibly related, the messianicity of the past does not point to a transcendent redeemer (the Messiah) but towards our profane actions. In his seminal essay on Benjamin's concept of historical time, Hamacher stresses this profane meaning of redemption:

Redemption, as Benjamin here talks about it, is meant most prosaically: a redeeming [Einlösung] of possibilities, which are opened with every life and are missed in every life. If the concept of redemption points towards a theology - and it does so without doubt and a fortiori in the context of the first thesis, which mentions the 'little hunchback' of theology - then this is not straightforwardly Judaeo-Christian theology, but rather a theology of the missed or the distorted hunchbacked - possibilities, a theology of missed, distorted or hunchbacked time. Each possibility that was missed in the past remains a possibility for the future, precisely because it has not found fulfilment. (Hamacher 2005: 40) 
25 Benjamin, however, past possibilities for happiness, which were missed and not fulfilled,
are not simply nullified. Rather, they persist in their state of unfulfillment and address the present.

The temporality and logic of these missed possibilities of the past cannot be mapped by a teleological understanding of the relation of actus and potentia. ${ }^{24}$ In happiness we are addressed by past possibilities that do not cease to haunt the present - a weak potentiality that silently, yet persistently calls for its retroactive redemption - an incompleteness of the past that forestalls any attempt to accomplish it in its unfulfilledness. This profane reading of messianic redemption is neither atheist nor theological proper. As Hamacher succinctly put it with reference to Benjamin's $1^{\text {st }}$ thesis On the Concept of History, theology here is a hunchbacked, distorted, entstellte theology - a theology of the distorted time of missed possibilities for happiness. This distorted time cannot be registered by positivist historiography or natural science. ${ }^{25}$ However, it is not merely an esoteric addressing but something that concerns the constitution of history as ontologically not fully completed.

The weak Kraft (power/force) that Benjamin perceives from a messianic perspective - as relatedness to redemption -, can also be experienced as a heavy weight, a burden that the past has put on the present. This other perspective is most famously articulated in the beginning lines of Marx's Eighteenth Brumaire, which Benjamin read in 1938 (cf. GS VII: 474).

Men make their own history, but they do not make it as they please; they do not make it under self-selected circumstances, but under circumstances existing already, given and transmitted from the past. The tradition of all dead generations weighs like a nightmare [Alp] on the brains of the living. (Marx 1975: 15)

The proper psychoanalytical name of this nightmare that weighs on the brains of the living might be trauma. If modernity's problem has always been that it cannot bury its dead, that it cannot "take leave of its past gaily [heiter]" (Benjamin 1999: 467, N 5a,2), as Benjamin cites Marx in the Arcades Project, the tradition of all dead generations is to stay with us. In an historico-psychoanalytical sense, the past is not dead but undead and that is why it haunts the present like a spectre, an Alp. ${ }^{26}$ This 'dark side' of the past as not yet historicized or fully symbolized prevents us from completing it. It is this lack or deficiency that reveals its messianic aspect once we perceive it from the perspective of the past. For Benjamin, hence, these "circumstances existing already, given and transmitted from the past" carry with them a secret index by which they are referred to redemption; - and it is this secret index or messianic imprint which prevents them from being fully historicized and settled in the historical text.

If we read Benjamin with Marx and Freud, what is repressed by the present (and keeps on returning like a traumatic Alp) can be retroactively redeemed by an authentic revolutionary act. Only the incalculable act of a new revolution can restore the crushed potentialities of failed revolutions - by fulfilling the past's weak, powerless potentia that has not been realized in the victorious course of history. ${ }^{27}$ The historical materialist's task is precisely to account for this weak power. In this sense, the revolutionary power of Benjamin's messianic thought is derived from its weakness. 


\section{Conclusion}

Benjamin's historical materialist concept of history does not serve the demands of history's dead but articulates on a more fundamental level the past's undeadness. The persisting claims of past generations of the downtrodden point towards a past that is not only oppressed by official historiography but which, moreover, did not take place. These claims bear witness to a secret striving for redemption - a redemption that completes and thereby repeats a past that has never happened. These crushed, oppressed potentialities prevent the past from being fully historicized. History thus remains incomplete. The messianic tension within history - the latter's relatedness to redemption - is the unstable site where this incompleteness can be turned into the complete. Ultimately, the messianic restitution of history would be the full actualization of the past's lost and oppressed potentialities. In the political everyday, however, profane restitution is not the entrance into the messianic Kingdom of pure actuality but an attempt to interrupt, derail the catastrophic course of actual history. "Classless society is not the final goal of historical progress but its frequently miscarried, ultimately [endlich] achieved interruption" (SW 4: 402). The weak messianic power is the revolving movement - the intermittent rhythm of happiness - of redeeming the past's hunchbacked, historically not realized potentiality. This redeeming act is the profane restitutio in integrum of history's capacity to have also taken a different course.

Paradoxically, it is precisely this messianic relatedness that gives rise to Benjamin's materialist, non-idealist, and non-positivist concept of history allowing for a truly profane concept of politics freed from all sorts of metaphysics, teleologies, historicisms, and determinist beliefs in historical progress. As Benjamin noted in the Arcades Project: "My thinking is related to theology as blotting pad is related to ink. It is saturated with it. Were one to go by the blotter, however, nothing of what is written would remain" (Benjamin 1999: 471, N 7a,7). Ultimately, a materialist reading of Benjamin's figure of the messianic is nothing else than the prosaic attempt to let go, release this charged ink to be able to concentrate on the unfinished, not-completed blotting pad. The discharge of this ink, however, leaves a distorted trace - that is the messianic without messianism. Although its script is nearly invisible and written inversely, we might decipher the illegible and liquefy the legible.

\section{BIBLIOGRAPHY}

Agamben, G. 1999. Potentialities: Collected Essays in Philosophy. (ed. and tr.) Daniel Heller-Roazen. Stanford : Stanford University Press.

Agamben, G. 2005. The Time That Remains: A Commentary on the Letter to the Romans. (tr.) Patricia Dailey. Stanford: Stanford University Press.

Anthropology \&amp; Materialism, 1 | 2013 
Aristotle. 1991. Complete Works of Aristotle. (ed.) Jonathan Barnes. Princeton: Princeton University Press.

Benjamin, W. 1999. Arcades Project. (tr.) Howard Eiland and Kevin McLaughlin. Cambridge, Mass.: Belknap Press of Harvard University Press.

Benjamin, W. 1972-1989 [GS]. Gesammelte Schriften. (ed.) Hermann Schweppenhäuser and Rolf Tiedemann. Vol. I-VII. Frankfurt am Main: Suhrkamp.

Benjamin. W. / Scholem, G. 1980. Briefwechsel 1933-1940. (ed.) Gershom Scholem. Frankfurt a. M.: Suhrkamp.

Benjamin, W. 1997. Gesammelte Briefe. (ed.) Christoph Gödde and Henri Lonitz. Vol. III. Frankfurt am Main: Suhrkamp.

Benjamin, W. 1996-2003 [SW]. Selected Writings. (ed.) Marcus Bollock and Michael W. Jennings. Vol. 1-4. Cambridge, Mass.: Belknap Press of Harvard University Press.

Cohen, H. 1919. Die Religion der Vernunft aus den Quellen des Judentums. Leipzig : Fock.

Derrida, J. 1999. Marx \& Sons. (tr.) Kelly Barry. In Ghostly Demarcations: A Symposium on Jacques Derrida's Specters of Marx. (ed.) Michael Sprinker. London and New York: Verso.

Derrida, J. 1994. Specters of Marx. The State of the Debt, the Work of Mourning and the New International. (tr.) Peggy Kamuf. London and New York: Routledge.

Friedlaender, S. 1918. Schöpferische Indifferenz. München: Müller.

Hamacher, W. 2006. Das Theologisch-politische Fragment. In Benjamin Handbuch. Leben-Werk Wirkung. (ed.) Burkhardt Lindner. Stuttgart: Metzler.

Hamacher, W. 2005, 'Now': Walter Benjamin on Historical Time. (tr.) N. Rosenthal. In Walter Benjamin and History. (ed.) Andrew Benjamin. London, New York: Continuum.

Jacobson, E. 2003. Metaphysics of the Profane: The Political Theology of Walter Benjamin and Gershom Scholem. New York: Columbia University Press.

Kafka, F. 1992. Nachgelassene Schriften und Fragmente. (ed.) Jost Schillemeit. Vol. II. Frankfurt am Main: Fischer.

Lear, J. 2000. Happiness, Death, and the Remainder of Life. Cambridge, Mass.: Harvard University Press.

Löwy, M. 2005. Fire Alarm. Reading Walter Benjamin's 'On the Concept of History'. (tr.) Chris Turner. London: Verso.

Marx, K. 1975. The Eighteenth Brumaire of Louis Bonaparte. New York: International Publishers.

Rosenzweig, F. 2005. The Star of Redemption. (tr.) Barbara E. Galli. Madison and London The University of Wisconsin Press.

Santner, E. L. 2001. On the Psychotheology of Everyday Life: Reflections on Freud and Rosenzweig. Chicago and London: The University of Chicago Press.

Scholem, G. 2000. Tagebücher. (ed.) Karlfried Gründer, Herbert Kopp-Oberstebrink, and Friedrich Niewöhner. Vol. 2, 1917-1923. Frankfurt a. M.: Jüdischer Verlag.

Taubes, J. 1993. Die politische Theologie des Paulus. (ed.) Aleida und Jan Assmann. München: Fink.

Wohlfarth, I. 2002. Nihilistischer Messianismus. Zu Walter Benjamins Theologisch-politischem Fragment. In 'Jüdische' und 'christliche' Sprachfigurationen im 20. Jahrhundert. (ed.) Ashraf Noor and Josef Wohlmuth Schöningh. Paderborn: Schöningh. 
Wohlfarth, I. 1986. "Immer radikal, niemals konsequent ...". Zur theologisch-politischen Standortsbestimmung Walter Benjamins. In Antike und Moderne. Zu Walter Benjamins "Passagen". (ed.) Norbert Bolz and Richard Faber. Würzburg: Königshausen und Neumann.

Wohlfarth, I. 1979. On the Messianic Structure of Benjamin's Last Reflections. Glyph 3, 148-212.

Wohlfarth, I. 1978. No-Man's-Land: On Walter Benjamin's ‘Destructive Character'. Diacritics 8.2., 47-65.

Žižek, S. 2000. The Fragile Absolute - or, Why is the Christian legacy worth fighting for. London and New York: Verso.

Žižek, S. 2001a. On Belief. London and New York: Routledge.

Žižek, S. 2001b. The Ticklish Subject: The Absent Centre of Political Ontology. London and New York: Verso.

Žižek, S. 2003. The Puppet and the Dwarf: the Perverse Core of Christianity. Cambridge, Mass.: MIT Press.

\section{NOTES}

1. This figure is not limited to the realm of thought but concerns the very boundary between epistemology (thinking) and ontology (being). As we shall see, the messianic is a 'blurry' figure. Only as a figure, neither as concept nor idea, it articulates a structural indeterminacy, a deviation, which questions any objectifying concept of history. In this sense, Benjamin's figure of the messianic is a figure of figuration and defiguration (Entstaltung); it lacks stability and consistency. This lack, however, is not a deficiency but its most precious asset: The messianic proves to be dysfunctional to all attempts to categorize and historicize it with regard to its textual presence.

2. In his later comments on this book, Derrida himself admits that "the interpretation of the messianic that I propose does not [...] much resemble Benjamin's" (Derrida 1999: 251).

3. To this extent, this hypothesis relies on a reading of the messianic that goes beyond the scope of this article. A detailed discussion is presented in my forthcoming book 'Teleologie ohne Endzweck'. Walter Benjamins Ent-stellung des Messianischen, Marburg, 2013.

4. This difference follows Derrida's strict separation of éschaton and telos, messianic eschatology and utopian teleology. Cf. Derrida 1994: 48.

5. Cf. Kafka: "Der Messias wird erst kommen, wenn er nicht mehr nötig sein wird, er wird nach seiner Ankunft kommen, er nicht am letzten Tag kommen, sondern am allerletzten" (Kafka 1992: 56f.).

6. Benjamin-citations are taken from the editions Selected Writings, ed. by Marcus Bollock; Michael W. Jennings, Cambridge, Mass., 4 vols., 1996-2003. Henceforth abbreviated SW, number of volume, and Gesammelte Schriften, ed. by Hermann Schweppenhäuser; Rolf Tiedemann, Frankfurt a. M. 7 vols., 1972-1989. Henceforth abbreviated GS, number of volume.

7. In his essay on Kafka (1934), Benjamin wrote that the Messiah "will not wish to change the world by force but will merely make a slight adjustment in it" (SW 2.2: 811). In the same passage Benjamin attributes this dictum to "a great rabbi" (ibid.) who is no one else than Gershom Scholem (cf. Scholem's letter to Benjamin, July 9, 1934, in Benjamin/Scholem 1980: 154). In his early notebooks Scholem mentions two contradictory trends of Jewish messianic thought: a transformative and revolutionary (cf. Scholem 2000: 285ff.).

8. Cf. Benjamin: "Der revolutionäre Wunsch, das Reich Gottes zu realisieren, ist der elastische Punkt der progressiven Bildung und der Anfang der modernen Geschichte. Was in gar keiner 
Beziehung aufs Reich Gottes steht, ist in ihr nur Nebensache." (GS I: 12; Benjamin quotes Friedrich Schlegel, Athenäum-fragment 222).

9. Cf. Benjamin: "Die Elemente des Endzustandes liegen nicht als gestaltlose Fortschrittstendenz zutage, sondern sind als gefährdetste, verrufenste und verlachte Schöpfungen und Gedanken tief in jeder Gegenwart eingebettet" (GS II: 75).

10. Cf. Löwy 2005: 4.

11. For the messianic meaning of "recapitulation" see also Agamben 2005: 75-77.

12. Cf. Benjamin: “... zumal, warum ich nicht daran denke, ,abzuschwören', wozu ich gestanden habe, warum ich mich des ,frühern' Anarchismus nicht schäme, sondern die anarchistischen Methoden zwar für untauglich, die kommunistischen ,Ziele' aber für Unsinn und für nichtexistent halte. Was dem Wert der kommunistischen Aktion darum kein Jota benimmt, weil sie das Korrektiv seiner Ziele ist und weil es sinnvoll politische Ziele nicht gibt“" (Benjamin, letter to Scholem, May 29, 1926, in Benjamin 1997: 159f.).

13. Although the exact date of the Theological-Political Fragment remains unknown, there is much evidence that Benjamin wrote it between 1920 and 1922. Many formulations can be traced back to fragments of the same period of time, e.g. Phantasie (GS VI: 114-117, ca. 1920/21) or the Schemata zum psychophysischen Problem (GS VI: 78-87, ca. 1922/23). Benjamin's English editors, however, suggest that it was written as late as 1937/38, cf. SW 3: 306. A succinct summary of the different positions of Benjamin's German editors Theodor W. Adorno, Gershom Scholem, and Rolf Tiedemann regarding the date of the Theological-Political Fragment is presented by Jacobson 2003: $22 f$.

14. Translation modified, cf. Benjamin, GS II: 203.

15. Cf. Taubes: "Es gibt einen Messias. Keinen Schmonzes, 'das Messianische', 'das Politische', keine Neutralisierung, sondern der Messias." (Taubes 1993: 98).

16. Cf. Hamacher 2006: 179.

17. Cf. Benjamin: "Die Ordnung des Profanen hat sich aufzurichten an der Idee des Glücks. Die Beziehung dieser Ordnung auf das Messianische ist eines der wesentlichen Lehrstücke der Geschichtsphilosophie. Und zwar ist von ihr aus eine mystische Geschichtsauffassung bedingt, deren Problem in einem Bilde sich darlegen läßt. Wenn eine Pfeilrichtung das Ziel, in welchem die Dynamis des Profanen wirkt, bezeichnet, eine andere die Richtung der messianischen Intensität, so strebt freilich das Glückssuchen der freien Menschheit von jener messianischen Richtung fort, aber wie eine andere Kraft durch ihren Weg eine andere auf entgegengesetztem Wege zu befördern vermag, so auch die profane Ordnung des Profanen das Kommen des messianischen Reiches. Das Profane also ist zwar keine Kategorie des Reiches, aber eine Kategorie, und zwar der zutreffendsten eine, seines leisesten Nahens. Denn im Glück erstrebt alles Irdische seinen Untergang, nur im Glück aber ist ihm der Untergang zu finden bestimmt. Während freilich die unmittelbare messianische Intensität des Herzens, des innern einzelnen Menschen durch Unglück, im Sinne des Leidens hindurchgeht. Der geistlichen restitutio in integrum, welche in die Unsterblichkeit einführt, entspricht eine weltliche, die in die Ewigkeit eines Unterganges führt und der Rhythmus dieses ewig vergehenden, in seiner Totalität vergehenden, in seiner räumlichen, aber auch zeitlichen Totalität vergehenden Weltlichen, der Rhythmus der messianischen Natur, ist Glück. Denn messianisch ist die Natur aus ihrer ewigen und totalen Vergängnis.

Diese zu erstreben, auch für diejenigen Stufen des Menschen, welche Natur sind, ist die Aufgabe der Weltpolitik, deren Methode Nihilismus zu heißen hat." (GS II: 203f.)

18. As Lear reminds us, in the English language this disruptive meaning of happiness as a "lucky break" can still be detected in the word "happenstance" (Lear 2000: 129). And indeed, "happenstance" is a compound word made of "happen" and "circumstance" - a lucky circumstance that unpredictably happened. See also Eric L. Santner's discussion of Lear in Santner 2001: $98 \mathrm{f}$. 
19. For Benjamin, this world is the realm of modern law, jurisdiction, and its fateful "guilt nexus of the living" (GS II: 175) violently striking at "bare life" (GS II: 199).

20. Although it is not very likely that Benjamin read Freud's essay Beyond the Pleasure Principle (1920) when writing the Theological-Political Fragment (between 1920 and 22), a close reading of Freud's paradoxical notion of "death drive" could shed light what Benjamin's obscure formulations of "eternity of downfall" and "eternal passing away" are pointing at. If we consider a Lacanian reading of the Freudian "death-drive," a stunning parallel can be detected. Referring to Jacques Lacan, Slavoj Žižek emphasizes: "far from being the same as the nirvana principle (the striving toward the dissolution of all life tension, the longing for the return to original nothingness), the death drive is the tension which persists and insists beyond and against the nirvana principle. In other words, far from being opposed to the pleasure principle, the nirvana principle is its highest and most radical expression. In this precise sense, the death drive stands for its exact opposite, for the dimension of the 'undead,' of a spectral life which insists beyond (biological) death" (Žižek 2003: 93). In line with this reading, Žižek insists that death drive "is the very opposite of dying, it is a name for the 'undead' eternal life itself, for the horrible fate of being caught in the endless repetitive cycle of wandering around in guilt and pain" (Žižek 2001b: 292). Following Jonathan Lear and Jean Laplanche, Žižek consequently criticizes Freud for his quasi biological, teleologically conceived notion of death drive: "Freud hypostasizes into a positive teleological principle the purely negative fact of breaks and interruptions which cannot be directly contained/integrated in the 'normal' teleologically oriented psychic economy; instead of accepting the fact of purely contingent interruptions which undermine the teleological functioning of the human psyche, he fantasizes a higher positive tendency/principle that accounts for these disruptions ('death drive')" (Žižek 2001a: 100). However far this structural analogy can be taken, an unbridgeable difference remains: Benjamin's eternal downfall proceeds without coercion whereas Freud's death-drive implies a compulsive pressure.

21. Cf. Benjamin: "Der Standort solcher schöpferischen Indifferenz ist natürlich niemals auf der goldenen Mittelstraße zu suchen. Denn diese Indifferenz ist dialektischer, unablässig erneuter Ausgleich, kein geometrischer Ort sondern Bannkreis eines Geschehens, Kraftfeld einer Entladung" (GS III: 138).

22. Benjamin, letter to Scholem, May 29, 1926, Gesammelte Briefe, Vol. III, pp. 158f. Translation is taken from Wohlfarth 1978: 57.

23. Cf. Benjamin: “[...] das Bild von Glück, das wir hegen, [ist] durch und durch von der Zeit tingiert [...], in welche der Verlauf unseres eigenen Daseins uns nun einmal verwiesen hat. Glück, das Neid in uns erwecken könnte, gibt es nur in der Luft, die wir geatmet haben, mit Menschen, zu denen wir hätten reden, mit Frauen, die sich uns hätten geben können. Es schwingt, mit andern Worten, in der Vorstellung des Glücks unveräußerlich die der Erlösung mit. Mit der Vorstellung der Vergangenheit, welche die Geschichte zu ihrer Sache macht, verhält es sich ebenso. Die Vergangenheit führt einen heimlichen Index mit, durch den sie auf die Erlösung verwiesen wird. [...] Ist dem so, dann besteht eine geheime Verabredung zwischen den gewesenen Geschlechtern und unserem. Dann sind wir auf der Erde erwartet worden. Dann ist uns wie jedem Geschlecht, das vor uns war, eine schwache messianische Kraft mitgegeben, an welche die Vergangenheit Anspruch hat. Billig ist dieser Anspruch nicht abzufertigen. Der historische Materialist weiß darum.“" (GS I: 693f.).

24. Whereas a traditional reading of the Aristotelian opposition of dynamis (potentia) and energeia (actus) grasps potentiality from the standpoint of actuality (after a potential has already been turned into actuality), Agamben's unconventional reading perceives actuality from the perspective of potentiality. In Aristotle's Metaphysics, we can at least find two interpretations of how to conceive of the temporal, logical, and ontological relation of potentiality and actuality: "To all such potentiality, then, actuality is prior both in formula and in substance; and in time it is prior in one sense, and in another not" (Aristotle 1991, Metaphysics: 1049b 10-12). "In time," as 
Aristotle unfolds this argument, "actuality is prior in this sense: the actual member of a species is prior to the potential member of the same species, though the individual is potential before it is actual" (ibid. 1049b 17). Against a reading of temporal sequence, Agamben, however, suggests "to consider the actuality of the potentiality to not-be" (Agamben 1999: 183). The idea of a "potentiality to not-be" or "impotentiality" (ibid.) does not only shift the perspective but affects the ontological status of potentialities as opposed to mere possibilities. As Agamben's editor and translator Daniel Heller-Roazen comments: "Unlike mere possibilities, which can be considered from a purely logical standpoint, potentialities or capacities present themselves above all as things that exist but that, at the same time, do not exist as actual things; they are present, yet they do not appear in the form of present things. What is at issue in the concept of potentiality is nothing less than a mode of existence that is irreducible to actuality" (Roazen in Agamben 1999: 14). With regard to Agamben's reading of Aristotle, we might call Benjamin's idea of missed chances for happiness impotentialities of the past - the undeterminable register of which is the "weak messianic power." Hence, restoring the full dimension of history's potentiality means to account for this remaining "impotentiality" (Agamben 1999: 181) - a potentiality that has not been actualized in the victorious course of history (cf. Agamben 2005: 97ff.).

25. Benjamin's messianic 'register' of the unredeemed claims of the past is the experience of remembrance [Eingedenken]: "What science has 'determined', remembrance can modify. Such remembrance [Eingedenken] can complete what is incomplete (happiness) and make incomplete what is complete (suffering). This is theology; but the experience of remembrance forbids us to grasp history in fundamentally atheological categories, however little we may [dürfen] try to write it in directly theological terms" (Benjamin 1999: 471, N 8,1).

26. The pressure of this nightmare is rendered more graphically by the German word Alp (also spelled Alb): An Alp is an elf, a figure from Germanic mythology that was believed to cause nightmares, Alpträume (literally: elf-dreams), by sitting pressingly on the chest of the sleeping person.

27. Cf. Žižek: "That is what [...] Walter Benjamin was trying to articulate in his explicitly antievolutionist notion of the Messianic promise of a revolutionary Act that will retroactively realize the crushed longings of all past, failed revolutionary attempts. What this means is that, in a properly historical perspective as opposed to evolutionist historicism, the past is not simply past, but bears within it its proper utopian promise of a future Redemption: in order to understand a past epoch properly, it is not sufficient to take into account the historical conditions out of which it grew - one has also to take into account the utopian hopes of a future that were betrayed and crushed by it - that which was 'negated', that which did not happen - so that the past historical reality was the way it was" (Žižek 2000: 89f.).

\section{ABSTRACTS}

This article discusses Walter Benjamin's messianic thought. Far from being a theological concept proper or a secularized motif of Judeo-Christian religion, the messianic is a complex figure of thought addressing a dimension of profane life that is neither culture nor nature but a 'weak power' within history allowing for a messianic standstill of the self-totalizing and selfeternalizing progress of capitalist 'real-history'. If the messianic is not about religion or political theology but concerns the profane order of the profane, how are we to conceive of it in a nonreductionist way? The underlying question of this article hence is: if the messianic is the 
theological name for something within the realm of the profane that is neither addressed by political philosophy nor life and social sciences, what is its relevance for a materialist understanding of history, historical time, and revolutionary politics?

Cet article discute la pensée messianique de Walter Benjamin. Loin d'être une notion proprement théologique ou un motif sécularisé de religiosité judéo-chrétienne, l'élément messianique est une figure conceptuelle complexe, qui permet d'aborder une dimension de la vie profane qui n'est ni la nature, ni la culture. Il s'agit plutôt d'un «faible pouvoir » qui court à travers l'histoire, et permet d'opérer une pause dans l' "histoire réelle », auto-totalisante et auto-éternalisante, du capitalisme. Si l'élément messianique ne concerne ni la religion, ni la théocratie, mais l'ordre profane du profane, comment pouvons-nous le concevoir d'une manière non-réductionniste ? La question sous-jacente à cet article est donc la suivante: Si l'élément messianique est le nom théologique donné à quelque chose qui se situe dans le domaine profane, et n'est pris en compte ni par la philosophie politique, ni par les sciences de la vie ou les sciences sociales, quelle peut être la pertinence d'une appréhension matérialiste de l'histoire, du temps historique, et des politiques révolutionnaires?

Abordar el pensamiento mesiánico de Walter Benjamin es el objetivo del presente artículo. Lejos de ser un concepto teológico adaptado o un motivo secularizado de la religión judeo-cristiana, lo mesiánico es una figura compleja del pensamiento capaz de conducir una dimensión de la vida profana que no es ni la cultura ni la naturaleza, sino una « débil fuerza » dentro de la historia que permite una parada mesiánica de lo que se auto-totaliza y auto-perpetúa como progreso de la « historia real » capitalista. Si lo mesiánico no incumbe la religión o la teología política, sino lo que afecta al profano orden de lo profano, ¿cómo podemos concebirlo sin reducirlo? La cuestión de fondo de este artículo puede formularse así: si lo mesiánico es el nombre teológico de algo dentro de la esfera de lo profano que no se rige ni por la filosofía política, ni por la vida o las ciencias sociales, ¿cuál es su importancia para una comprensión materialista de la historia, para el tiempo histórico y para las políticas revolucionarias?

\section{INDEX}

Palabras claves: Benjamin Walter, materialismo, teología, mesianismo, historia

Mots-clés: matérialisme, théologie, messianisme, histoire

Keywords: materialism, theology, messianic, history 